\title{
NUCLEAR REGULATORY COMMISSION ISSUANCES
}

\author{
March 1998
}

This report includes the issuances received during the specified period from the Commission (CLI), the Atomic Safety and Licensing Boards (LBP), the Administrative Law Judges (ALJ), the Directors' Decisions (DD), and the Decisions on Petitions for Rulemaking (DPRM)

The summaries and headnotes preceding the opinions reported herein are not to be deemed a part of those opinions or have any independent legal significance.

DISTRIBUTION OF THIS DOCUMENT IS UNLIMITED

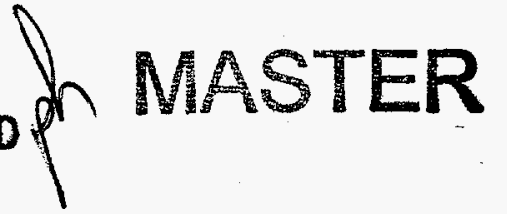

\section{U.S. NUCLEAR REGULATORY COMMISSION}

Prepared by the

Office of the Chief Information Officer

U.S. Nuclear Regulatory Commission

Washington, DC 20555-0001

$(301-415-6844)$ 


\section{COMMISSIONERS}

Shirley A. Jackson, Chairman

Greta J. Dicus

Nils J. Diaz

Edward McGaffigan, Jr.

B. Paul Cotter, Jr., Chief Administrative Judge, Atomic Safety \& Licensing Board Panel 


\section{DISCLAIMER}

This report was prepared as an account of work sponsored by an agency of the United States Government. Neither the United States Government nor any agency thereof, nor any of their employees, makes any warranty, express or implied, or assumes any legal liability or responsibility for the accuracy, completeness, or usefulness of any information, apparatus, product, or process disclosed, or represents that its use would not infringe privately owned rights. Reference herein to any specific commercial product, process, or service by trade name, trademark, manufacturer, or otherwise does not necessarily constitute or imply its endorsement, recommendation, or favoring by the United States Government or any agency thereof. The views and opinions of authors expressed herein do not necessarily state or reflect those of the United States Government or any agency thereof. 


\section{DISCLAIMER}

Portions of this document may be illegible electronic image products. Images are produced from the best available original document. 


\section{CONTENTS}

Issuance of the Nuclear Regulatory Commission

\section{U.S. ENRICHMENT CORPORATION}

(Paducah, Kentucky)

Docket 70-7001

MEMORANDUM AND ORDER, CLI-98-2, March 19, 1998

Issuance of Director's Decision

NORTH ATLANTIC ENERGY SERVICE CORPORATION

(Seabrook Station, Unit 1)

Docket 50-443 (License No. NPF-86)

DIRECTOR'S DECISION UNDER 10 C.F.R. \$ 2.206,

DD-98-3, March 17, 1998 
Commission Issuances 
UNITED STATES OF AMERICA

NUCLEAR REGULATORY COMMISSION

COMMISSIONERS:

\author{
Shirley Ann Jackson, Chairman \\ Greta Dicus \\ Nils J. Diaz \\ Edward McGaffigan, Jr.
}

\title{
U.S. ENRICHMENT CORPORATION
}

(Paducah, Kentucky)

March 19, 1998

The Commission denies USEC's petition, submitted pursuant to 10 C.F.R. $\$ 76.62(\mathrm{c})$, for review of the Director's Decision that partially denied USEC's request for an amendment to the Certificate of Compliance for the Paducah Gaseous Diffusion Plant. The Commission rejects all technical bases for the petition asserted by USEC and allows the Director's Decision to become final.

\section{MEMORANDUM AND ORDER}

\section{INTRODUCTION}

On December 16, 1997, the U.S. Nuclear Regulatory Commission published, in the Federal Register (62 Fed. Reg. 65,823), notice of amendment and partial denial of amendment application to the Certificate of Compliance GDP-1 for the U.S. Enrichment Corporation (USEC), Paducah Gaseous Diffusion Plant (referred to hereafter as Paducah or PGDP), located in Paducah, Kentucky. USEC, or any person whose interest may be affected and who had submitted written comments in response to the Federal Register (62 Fed. Reg. 41,101) notice that noticed the amendment request was eligible to file a petition to the Commission requesting review of the Director's Decision within 15 days after publication of the Director's Decision. 10 C.F.R. $\$ 76.62(\mathrm{c})$. 
NRC received one petition for review of the Director's Decision. This Memorandum and Order addresses the petition for review and the issues raised in the petition. For reasons set forth below, the petition is denied in its entirety.

\section{PETITION FOR REVIEW}

By letter dated December 30, 1997, USEC, holder of Certificate of Compliance for the PGDP (GDP-1), petitioned for Commission review of the Director's Decision. The petition was docketed at NRC on December 30, 1997.

\section{BACKGROUND}

The September 15, 1995 application from USEC for certification of the PGDP contained an analysis of the potential impacts of earthquakes that was based on a 1985 U.S. Department of Energy (DOE) Safety Analysis Report (SAR). DOE was in the process of conducting new studies and analyses to update the 1985 SAR at the time the application was submitted to the NRC. DOE concluded that two (Buildings C-331 and C-335) of four large processing buildings could suffer structural failure at relatively low seismic demand, beginning at $0.05 \mathrm{~g}$ peak ground acceleration (PGA). DOE concluded that damage could include roof and floor collapse, and concomitant equipment damage. The principal failure mechanism identified was seismic displacement, beyond tolerance, of sliding beam roof and floor sections supported by rocker arms. DOE considered the potential for large uranium hexafluoride releases coincident with a loss of structural confinement to be an unreviewed safety question and outside the existing safety basis for plant authorization. (DOE Letter to USEC, September 22, 1995.) To address these concerns, DOE issued a "Directive for Information" to USEC on September 22, 1995. Because DOE considered USEC's initial response to be unacceptable (DOE Letter to USEC, October 31, 1995), DOE issued a "Directive for Corrective Action and Compensatory Actions for Operations in Buildings C-331 and C-335" to USEC on October 31, 1995. This second directive required USEC to "develop and initiate action(s) to ensure that the response of the rocker supported floor sections of each building can withstand the expected seismic demand. . .." DOE subsequently performed the seismic analyses and conceptual design of the modifications to the buildings, and is funding activities associated with the seismic upgrades, including installation of the proposed modifications. (USEC Letter to NRC, June 30,1997.)

The Commission was informed by the Staff in SECY 96-054 and during the March 22, 1996 Commission briefing concerning the status of certification, 
that DOE had identified structural weaknesses in certain buildings at Paducah and that USEC would implement compensatory measures while carrying out plant structural modifications to raise the seismic capacity of these buildings (hereinafter referred to as "structural modifications"). The Commission was informed that the Staff intended to certify on the seismic issue, based on: (1) a firm commitment to upgrade to withstand a postulated 250-year earthquake event; (2) adequate justification for continued operation; (3) continuation of compensatory measures; and (4) reevaluation during future certification reviews. In SECY 96-180 and in a Commission meeting held on August 28, 1996, the Commission was informed that the structural modifications were scheduled to be completed by late 1997 and that interim compensatory measures would continue until these structural modifications are installed. The Commission was also informed about potential weaknesses in the seismic hazard analysis. The seismic hazard analysis performed by DOE to support certification did not use the most recent seismic data in the analysis which, if included, could make the resulting evaluation-basis earthquake greater than that used by DOE. Therefore, a seismic hazard analysis using updated data was required to be performed. NRC specified that if the new seismic hazard analysis reflected greater hazards than DOE's current analysis, the need for further plant modifications would be subject to backfit evaluation. Because this issue would not be resolved by the time of initial certification, the issue was required to be addressed in the Compliance Plan. DOE agreed and prepared Compliance Plan Issue 36, "Seismic Capability of Buildings C-331 and C-335." USEC submitted Compliance Plan Issue 36 in a letter dated July 18, 1996. The Compliance Plan called for the structural modifications to be completed by December 31, 1997, and continuation of interim, compensatory measures. The Compliance Plan also required USEC to submit the final design plans to NRC. The Compliance Plan included a commitment for USEC to perform a new seismic hazard analysis by December $1,1997$.

By letter dated April 23, 1997, USEC submitted an amendment request to obtain NRC approval of three Unreviewed Safety Questions (USQs) associated with the seismic upgrades and to extend the completion date until 15 months after approval of the amendment request. On July 31, 1997, USEC revised its amendment request to further delay completion of the seismic modifications until 18 months after: (1) USEC submits, and NRC approves, the final design of the structural modifications; (2) NRC completes its review of the three USQs; (3) NRC completes its review of the seismic analysis included in the upgraded Safety Analysis Report (SARUP); and (4) NRC approves an updated seismic hazard analysis. In the July submittal, USEC also requested NRC approval of: (1) the resolution of three USQs it had identified; (2) revising the Compliance Plan to reference only sheltering concerning emergency preparedness; (3) revising the Compliance Plan to reflect that the final design of the modifications 
is complete; and (4) revising the Compliance Plan to reference a report prepared by Lawrence Livermore National Laboratory (LLNL) entitled "Paducah Gaseous Diffusion Plant Seismic Risk Study (UCRL-ID-126275)," hereinafter referred to as the LLNL report, or the LLNL study. DOE had contracted with LLNL to produce this study of the PGDP seismic risk to verify the justification for continued operation (JCO) on the Compliance Plan seismic issue.

NRC and DOE signed a Memorandum of Understanding (MOU), which was published in the Federal Register on November 5, 1997 (62 Fed. Reg. 59,910). The NRC/DOE MOU requires that all modifications to the Compliance Plan be approved by DOE before submitting any such changes to NRC. By letter dated October 23, 1997, USEC was informed of the need to obtain DOE approval before submitting Compliance Plan changes. However, in that letter, NRC stated that, for all pending Compliance Plan amendments, it would coordinate with DOE in lieu of requiring their resubmittal, and delaying consideration of such pending amendments, while USEC sought DOE approval. In accordance with this process, NRC discussed the proposed Compliance Plan changes that resulted from the NRC Staff's review of USEC's amendment request with DOE. DOE supported NRC's position on the changes (NRC Letter to USEC, December 8 , 1997) and indicated that it believes that the modifications should be made without further delay. DOE also described the limitations of the LLNL report submitted by USEC.

The Director's Decision on the amendment appeared in the Federal Register on December 16, 1997 (62 Fed. Reg. 65,823). The decision announced the intention to approve in part, and deny in part, USEC's request. The decision approved resolution of the USQs; approved revising the Compliance Plan to reference only sheltering; approved revising the Compliance Plan to reflect that the final design of the modifications is complete; denied revising the Compliance Plan to reference a report prepared by LLNL; and denied delaying completion of the structural modifications until 18 months after the Staff completes reviews of all other seismic material requested by USEC. Instead, the Staff established a completion date for the structural modifications of June 30, 1999 (approximately 18 months after issuance of the Director's Decision).

On December 30, 1997, USEC submitted to the Commission a "Petition Requesting Commission Review of Director's Decision Denying in Part USEC Certificate Amendment Request Regarding Paducah Plant Seismic Upgrades." In the petition, USEC requested that the Commission review only that portion of the Director's Decision that denied parts of USEC's July 31, 1997 application for amendment to its Certificate of Compliance for the PGDP. Specifically, USEC requested that the Commission extend the deadline for completion of the structural modifications until 18 months after NRC has completed the reviews and approvals described in USEC's July 31, 1997 certificate amendment application. 


\section{ANALYSIS AND RESPONSE TO ISSUES RAISED IN THE USEC PETITION}

The USEC petition enumerated five supporting reasons for submitting the petition, which we will refer to as USEC Issues 1 through 5. In USEC Issues $2,3,4$, and 5, the Petitioner requests that NRC complete a review of seismic information submitted by USEC before installation of the modifications is begun. The Petitioner requests NRC review of four documents. The effects of a delay in installing the structural modifications, which would result from reviewing all four documents, are addressed in USEC Issue 6, separately from other issuespecific information. USEC Issues 1 through 6 are addressed below.

\section{A. USEC Issue 1: The Structural Modifications Were Originally Ordered by DOE Based on Incomplete Technical Information}

The Petitioner argues that the DOE issued a directive to install the modifications based on work being performed as part of its site-wide SARUP effort before it had performed the SARUP consequence analysis to determine what the impact of such a structural failure might be on workers or the offsite public. The Petitioner further argues that DOE had not yet completed all its planned SARUP structural analyses to fully assess the seismic capacity of the other buildings at the PGDP site before ordering the modifications. The Petitioner believes that, although the result of a seismic hazard analysis, required by NRC, indicates that consequences in excess of the existing SAR are possible, they do not justify installation of the structural modifications being planned based on the recently completed seismic risk analysis conducted by LLNL.

The fact that DOE had not completed all of its planned SARUP structural analyses to fully assess the seismic capacity of the other buildings at PGDP, before ordering the modifications, has no bearing on the currently planned modifications. DOE had completed the seismic structural analyses for the buildings in question - C-331 and C-335. The DOE review of the SARUP information indicated that the two buildings would begin to fail at an $0.05 \mathrm{~g}$ earthquake (approximately 80-year return period) instead of failing at an $0.15 \mathrm{~g}$ earthquake (with a return period of approximately 250 years), ${ }^{1}$ as assumed in the current SAR. Therefore, DOE issued a directive to USEC that ordered USEC to modify the buildings. DOE has since completed the SAR upgrade analyses and DOE's belief that these modifications are needed remains unchanged (DOE Letter to NRC, January 5, 1998). It is possible that the NRC review of the

\footnotetext{
${ }^{1}$ The annual probability of occurrence of an 80-year-return-period earthquake is $1.25 \times 10^{-2}$; the annual probability of occurrence of a 250 -year-return-period earthquake is $4 \times 10^{-3}$.
} 
SARUP could result in the requirement for modifications to other buildings and equipment at PGDP. However, the need for additional structural modifications to other buildings does not alter the need for the structural modifications to Buildings C-331 and C-335.

USEC also argues that the LLNL report provides justification for not installing the structural modifications at all. In a January 5, 1998 letter to NRC, DOE documented that it contracted with LLNL to perform a review of the PGDP seismic analysis to verify the content of the JCO that was required for the Compliance Plan seismic issue. The review was intended as a scoping analysis to provide a general overall risk perspective and was performed to ensure that PGDP could continue to operate in a safe manner for a limited period of time until the appropriate modifications could be performed. In the letter, DOE states that the LLNL review was never intended to support continued operation for an indefinite period of time without the proposed modifications, and the methodology and rigor used in the study were inconsistent with this intention. DOE reviewed the report and identified four limitations. We conclude that the LLNL report contains limitations and does not support eliminating installation of the modifications. The LLNL report and its limitations are further discussed in Section C, USEC Issue 3.

We find that the Petitioner has not substantiated that DOE's technical basis for ordering the structural modifications was based on incomplete information. Therefore, we reject this basis for challenging the Director's Decision.

\section{B. USEC Issue 2: The Updated Seismic Risk Analysis That Was Required by NRC Indicates a Higher Evaluation Basis Earthquake (EBE) Than the Modifications Are Based Upon}

The Petitioner is concerned that NRC may require a level of seismic risk management to be applied to the C-331 and C-335 buildings that will not be met by the planned structural modifications. The planned structural modifications were designed to meet an earthquake with a peak ground acceleration of $0.15 \mathrm{~g}$, which, at the time of certification, was thought to have a recurrence interval of approximately 250 years. The results of a recently completed USEC seismic hazard study for the Paducah site indicate that a 250-year-recurrence-period earthquake has a peak ground acceleration of $0.165 \mathrm{~g}$. The Petitioner believes that any modifications should await an NRC determination of a final earthquake acceleration value because the cost of backfitting more stringent requirements to these modifications after they are begun may significantly exceed the cost of incorporating them into the initial design and could force substantial rework.

This issue was already addressed during the certification process. One of NRC's concerns during certification was that DOE had not used the most recent seismic data to conduct the seismic hazard analysis (DOE used the 1985 
data - more recent information after 1985 was not considered). NRC believed that the actual seismic event might be greater than the $0.15 g$ used by DOE. For this reason, it insisted that the Compliance Plan include a USEC commitment to perform a new seismic hazard analysis by December 1, 1997. During USEC/DOE discussions of the draft Compliance Plan, USEC suggested delaying the modifications until after the new seismic hazard analysis was complete. Both DOE and NRC found this approach to be unacceptable. NRC agreed that if the new seismic hazard analysis reflected greater hazards than DOE's current analysis, the need for further plant modifications would be subject to backfit evaluation.

The effect of the delay in installing the structural modifications caused by the additional time required to review the seismic hazard study, in conjunction with all the other seismic documents requested by USEC, is discussed in USEC Issue 6.

Petitioner's concern that the cost of backfitting to a higher earthquake acceleration value, after the current modifications are begun, may exceed the cost of incorporating them into the initial design, is without merit since any modifications necessary to meet an incremental increase in earthquake level, above the compliance level of $0.15 \mathrm{~g}$ for which the modifications are designed, will be subject to backfit evaluation, in accordance with NRC regulations, where cost - including cost of any rework - will be a factor. Petitioner fears a threat that has yet to materialize, and may never do so. If, in the future, Staff imposes a requirement for additional seismic upgrade work which USEC seeks to contest, USEC will have an opportunity to do so at that time. Therefore, we reject this issue as a basis for challenging the Director's Decision.

\section{USEC Issue 3: A Recent Study Shows Actual Health Risks from a Postulated Seismic Event To Be Low}

The Petitioner believes that the LLNL report that it has submitted calls into question the justification for the planned structural modifications and therefore, before the modifications are undertaken, NRC should consider the results of the report and determine whether the expenditure of funds to undertake the modifications is appropriate or necessary. Elsewhere in the petition, the Petitioner states "that it would be compelled to make plant modifications, incurring competing risks identified in the USQs, even though the modifications may be determined to be inadequate or perhaps even unnecessary."2

\footnotetext{
${ }^{2}$ Note that the Compliance Evaluation Report (NRC Letter to USEC, December 8, 1997) concluded that the risks associated with the USQs would be minimized and acceptable as a result of preventive and mitigative measures that USEC would implement.
} 
DOE commissioned the LLNL study to verify the justification for continued operation (JCO) in Compliance Plan Issue 36. Compliance Plan Issue 36 required that the modifications be installed by December 31, 1997. The LLNL report was provided to DOE on March 17, 1997, after NRC assumed regulatory oversight. The LLNL report was submitted to NRC, for information, on June 30, 1997 - USEC did not, however, request NRC to review the report. We also note that USEC has not requested the NRC Staff to approve elimination of the requirement for the seismic upgrade modifications.

The LLNL report concludes, as stated in USEC's petition, that "even though the probability of earthquake damage to Buildings C-331 and C-335 is relatively high in their current condition, the health risk is low." However, the report further concludes that

[t]he risk model includes a very approximate model of the on-site population exposure to $\mathrm{UF}_{6}$ and therefore, the model is not an accurate predictor of the total risk to the worker. For example, the risk model only includes the risk due to $\mathrm{UF}_{6}$ release, but the workers in buildings are also exposed to the risks from falling structures, which have not been considered.

The report also concludes,

[i]f a severe earthquake were to occur, some on-site fatalities are likely because of the concentration of people. The analysis does not indicate this result because it does not model the high concentrations of toxic materials near the point of release, nor is there any consideration given to "normal" earthquake hazards, such as falling debris.

In a January 5, 1998 letter to NRC, DOE documented that it contracted with LLNL to perform a review of the PGDP seismic analysis to verify the content of the JCO that was required for the Compliance Plan seismic issue. The review was intended as a scoping analysis to provide a general overall risk perspective and was performed to ensure that PGDP could continue to operate in a safe manner for a limited period of time until the appropriate modifications could be performed. In the letter, DOE states that the LLNL review was never intended to support continued operation for an indefinite period of time without the proposed modifications, and the methodology and rigor used in the study were inconsistent with this intention. DOE reviewed the report and identified four limitations in the report as follows: (1) The review did not include the full matrix of contributors to risk from all the potential failure modes and effects - only those considered more significant; (2) the review approximated the sliding beam failure with a modified S-shaped typical building fragility curve instead of the actual PGDP Building C-331 and C-335 sliding beam fragility curve, which exhibits abrupt failure; (3) the review did not address the risk to all onsite workers; and (4) the review did not address long-term, ground-hugging releases. (DOE Letter to NRC, January 5, 1998.) DOE concluded, in summary, that the LLNL review 
was prepared for a specific purpose and would require substantial additional effort to resolve regulatory questions and concerns if applied for uses other than to support a JCO for a short period of time. It should be noted that when the LLNL study was prepared, completion of the modifications was scheduled for December 31, 1997. DOE further concluded that it does not consider the elimination of the proposed seismic upgrades for PGDP as a viable option and that it pursued an accelerated schedule for completion of the modifications when it had regulatory authority over PGDP.

DOE, which requested this report, believes that the LLNL report contains limitations that would prevent its use other than for its intended purpose, to support a JCO for a short period of time. Therefore, we find the report cannot be used to support elimination of the modifications altogether. The seismic modifications needed to meet a $0.15 \mathrm{~g}$ earthquake are necessary to satisfy the current approved Compliance Plan and are not subject to backfit evaluation. Regarding the Petitioner's concern about the expenditure of funds, modifications needed to resist an earthquake above $0.15 g$ are subject to backfit evaluation where cost - including the cost of any rework - is a consideration. Further, the cost of any modifications necessary to meet a $0.15 \mathrm{~g}$ earthquake is fully reimbursable by DOE (USEC Letter to NRC, June 30, 1997) - and DOE has indicated, in its January 5 letter, that the currently planned structural modifications should be installed. ${ }^{3}$

We find that the limitations in the scope and content of the LLNL report as discussed earlier prevent reliance on this report as a basis for reconsideration of the denial of portions of the amendment to the Compliance Plan. Therefore, we reject this basis for challenging the Director's Decision.

\section{USEC Issue 4: NRC Has Not Yet Reviewed or Approved Final Design Information Provided by USEC}

The Petitioner believes that final design information submitted by the Petitioner should be reviewed by NRC before the modifications are installed. The Petitioner believes that there is a significant risk that NRC could later require expensive changes.

USEC correctly states, in its petition, that NRC has not yet reviewed or approved final design information provided by USEC. The Compliance Plan, as noted by USEC in its petition, does not require the Staff to review the final design information before requiring USEC to proceed with actual modifications.

\footnotetext{
${ }^{3}$ In accordance with a Memorandum of Understanding (MOU) (62 Fed. Reg. 59,910) with DOE, in midNovember 1997, the Staff discussed with DOE the proposed Compliance Plan changes from USEC's amendment request. DOE supported NRC's position on the changes, as reflected in the Staff's Compliance Evaluation Report (CER) on USEC's amendment request.
} 
$\mathrm{NRC}$, in making an informed safety decision, relies extensively on the technical competence and integrity of licensees and certificate holders. NRC, in issuing certificates to USEC, has determined that USEC, as the organization responsible for safety at the gaseous diffusion facilities, is competent and has the technical expertise to operate and maintain the facility. Although NRC did not review the final design in detail, DOE performed the initial conceptual design of the structural modifications, before NRC assumed regulatory oversight of the GDPs and is funding USEC's activities associated with the seismic modifications (USEC Letter dated June 30, 1997).

NRC did require USEC, the certificate holder, to provide the proposed structural modification design information, thus allowing the Staff to make a detailed review if the Staff's initial overview indicated it was warranted. NRC selectively reviews submittals to allow Staff to continue to assess the status of safety at a facility. NRC would perform a detailed computational validation for the type of seismic calculations used to implement modifications such as those proposed by USEC, if it were determined that a detailed review were necessary because of readily evident or perceived inadequacies or if the Staff concludes that the review is necessary to support its safety decision. NRC, based on a limited overview of the proposed modification, has not raised any concerns with respect to the final design information supplied by USEC. Consequently, a detailed prior NRC review of the proposed structural modification was not performed, and is not planned.

Petitioner's request for NRC to review final design information before the modifications are installed because of the risk that NRC may later require expensive changes is without merit. USEC, as the certificate holder, bears the responsibility for the accuracy of the modifications and, if the modifications contain errors, USEC will be required to correct any errors, regardless of when they are discovered. If the upgraded seismic hazard analysis is eventually found to support an increase above $0.15 \mathrm{~g}$ and the current modifications are found to be insufficient to resist an earthquake greater than $0.15 \mathrm{~g}$, then any additional modifications needed to increase the resistance from $0.15 \mathrm{~g}$ to the higher value will be subject to backfit evaluation (see Section B, USEC Issue 2). Therefore, we reject this basis for challenging the Director's Decision.

\section{E. USEC Issue 5: The NRC Has Not Yet Reviewed PGDP Building and Equipment Seismic Capacity Information Submitted by USEC as Part of the Required SARUP Submittal}

The Petitioner believes that the SARUP information submitted to NRC in accordance with the requirements of the Compliance Plan should be reviewed by NRC before any seismic modifications proceed. According to USEC, the SARUP information indicates that areas of two other buildings (i.e., two 
product withdrawal buildings, Buildings C-310 and C-315) are also susceptible to seismic-induced damage. The Petitioner argues that the SARUP information shows that the planned modifications are not, by themselves, effective in reducing the seismic risk at PGDP since the C-331 and C-335 failures do not dominate seismic risk at the site. The Petitioner asserts that the SAR analysis shows that only a modest risk reduction would be achievable by a comprehensive set of modifications to harden the plant to resist an EBE. The Petitioner further states that the LLNL report demonstrates that even onsite consequences of a seismic event constitute a low seismic risk.

It is possible that the Staff's review of the SARUP could result in the requirement for modifications to other buildings and equipment; however, this has no bearing on the currently planned modifications. Any requirement for new modifications to other buildings that may result from the Staff's review of the SARUP would not change the need for the currently planned structural modifications to Buildings C-331 and C-335. Furthermore, Petitioner's assertion that the SARUP analysis demonstrates that the structural modifications in Buildings C-331 and C-335 would not be effective in reducing seismic risk at PGDP, since the C-331 and C-335 failures do not dominate risk, ignores the fact that the SARUP analysis assumes that the seismic upgrades to C-331 and C-335 have already been completed. As stated above, the presence of greater risks from other sources would not obviate the need for the already planned upgrades. NRC is reviewing the SARUP analysis and will take actions, as appropriate. Regarding the Petitioner's reliance on the LLNL report, we find that the limitations in the scope and content of the LLNL report prevent reliance on this report (see Section C, USEC Issue 3).

We find that Petitioner's request that the Staff review the SARUP information before installation of the modifications, is without merit. There is no linkage between the currently planned modifications and any other future modifications to other buildings. We also find that the limitations in the scope and content of the LLNL report as discussed earlier prevent reliance on this report as a basis for reconsideration of the denial of portions of the amendment to the Compliance Plan. Therefore, we reject this basis for challenging the Director's Decision.

\section{F. USEC Issue 6: Public Health and Safety Will Be Protected During the Requested Delay}

The Petitioner believes that the actual risk of harm is low, based on the LLNL report. Further, the Petitioner believes that, since NRC approved an 18-month extension to complete installation of the modifications in its CER, an additional 3- to 4-month delay (Petitioner estimate) for the Staff to review the information requested by the Petitioner is acceptable, based on the current JCO.

According to DOE, the LLNL review 
was intended as a scoping analysis to provide a general overall risk perspective and was performed to ensure that PGDP could continue to operate in a safe manner for a limited period of time until the appropriate modifications could be performed. The LLNL review was never intended to support continued operation for an indefinite period of time without the proposed modifications. ...

(See Section C, USEC Issue 3 and DOE Letter dated January 5, 1998.) At the time the LLNL review was being performed, it was expected that the modifications would be completed by December 31, 1997, according to the commitment date in the Compliance Plan.

The currently planned modifications, as designed, will substantially improve the seismic resistance of the buildings above the current level of $0.05 \mathrm{~g}$, substantially decreasing the risk to the health and safety of the workers, and could begin to be installed immediately. In addressing each of the Petitioner's issues above, we have discussed why the reviews requested by the Petitioner are not needed prior to beginning the structural modifications.

Moreover, the Petitioner's estimate of delay is inaccurate. The delay in completing installation of the modifications resulting from having the Staff complete the reviews requested by USEC in the amendment request (i.e., USEC's final design of the structural modifications, seismic analyses in USEC's SARUP, and the seismic hazard analysis submitted by USEC on December 1, 1997) could range from at least several months, if the modifications were found to be acceptable, to several years, if the Staff concludes that the modifications are not completely accurate, either because of USEC design errors or because a higher earthquake level is appropriate (encompasses the time while new modifications are designed by USEC, reviewed and approved by NRC, and then fabricated and installed by USEC). NRC believes that the risk associated with operating and working in the buildings, in their current condition, warrants beginning the structural modifications without further delay.

The Petitioner's characterization that NRC approved an 18-month extension in the absence of structural modifications is inaccurate. The Staff approved an 18-month extension to complete the modifications, with the knowledge that the structural resistance of the buildings would gradually improve, over the 18 months, as the modifications are installed.

Petitioner's argument that public health and safety will be protected during the requested delay has not been substantiated. Therefore, we reject this basis for challenging the Director's Decision.

In summary, having addressed the individual arguments of USEC in detail above, the Commission finds that USEC has offered no sustainable basis for its request for review of the Director's Decision. The Commission finds that the interest of protecting public and worker health and safety at Paducah dictates that the seismic modifications required by the Compliance Plan be implemented 
without delay as stated in the Director's Decision published in the Federal Register on December 16, 1997.

For the foregoing reasons:

The petition for review, dated December 30, 1997, from the United States Enrichment Corporation, of Bethesda, Maryland, is denied in its entirety.

It is so ORDERED.

For the Commission ${ }^{4}$

JOHN C. HOYLE

Secretary of the Commission

Dated at Rockville, Maryland,

this 19th day of March 1998.

\footnotetext{
${ }^{4}$ Commissioner Diaz was not available for the affirmation of this Order. Had he been present, he would have affirmed the Order.
} 
Directors'

Decisions

Under

10 CFR 2.206

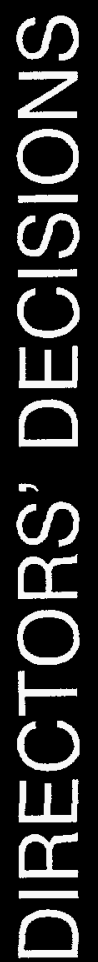




\title{
UNITED STATES OF AMERICA NUCLEAR REGULATORY COMMISSION
}

\section{OFFICE OF NUCLEAR REACTOR REGULATION}

\author{
Samuel J. Collins, Director
}

In the Matter of

Docket No. 50-443

(License No. NPF-86)

\section{NORTH ATLANTIC ENERGY SERVICE CORPORATION \\ (Seabrook Station, Unit 1)}

March 17, 1998

The Director of the Office of Nuclear Reactor Regulation denied a petition filed by The Seacoast Anti-Pollution League. The petition requested that the NRC: (1) suspend the operating license for Seabrook Station until such time as a thorough root-cause analysis of the reasons underlying the development of leaks in piping of the " $B$ " train of the residual heat removal (RHR) system is conducted; (2) review weld documentation and inspection documentation in the leakage area; (3) review the qualification of the piping involved; (4) review the plant's quality assurance procedures for welds and piping; (5) address past allegations of improper welding and installation of substandard piping at Seabrook Station in its review and relate the alleged piping and weld deficiencies to other plant systems; and (6) delay the restart of Seabrook Station following repairs to the RHR piping system, pending completion of all requested actions. The Director concluded that no evidence was found of improper welding practices or substandard piping that contributed to pipe leakage or that would result in generic implications to other plant systems and that would require suspension of Seabrook's operating license. 


\section{INTRODUCTION}

On December 18, 1997, Ms. Jane Doughty submitted a petition to the Executive Director for Operations of the U.S. Nuclear Regulatory Commission (NRC) on behalf of The Seacoast Anti-Pollution League requesting that the operating license for Seabrook Station be suspended until such time as a thorough root-cause analysis of the reasons underlying the development of leaks in piping of the " $B$ " train of the residual heat removal (RHR) system is conducted. The leakage was reported by North Atlantic Energy Service Corporation, the Licensee for Seabrook Station, on December 5, 1997.

The petition requested that the restart of the Seabrook Station following repairs to the RHR system piping be delayed until all such actions requested by the petition are taken. On January 15, 1998, the NRC informed the Petitioner in an acknowledgment letter that on the basis of the Licensee's preliminary analysis of the cause of the pipe leakage, the NRC Staff found no reason to prevent the plant from restarting. The acknowledgment letter further informed the Petitioner that her petition had been referred to the Office of Nuclear Reactor Regulation pursuant to 10 C.F.R. $\$ 2.206$ for preparation of a Director's Decision and that action would be taken within a reasonable time regarding the specific concerns raised in the petition.

\section{DISCUSSION}

The petition requests, in part,

that the operating license for the Seabrook Station Nuclear Power Plant [Seabrook Station] be suspended until such time as a thorough root cause analysis of the reasons underlying the development of leaks . . . in piping in the "B" train of the Residual Heat Removal (RHR) system is conducted, including but not limited to a review of documentation associated with welds in the area of the leakage and their associated inspection documentation, a review of the qualification of the piping involved, and a review of the procedures for ongoing assurance of weld and piping quality at the plant.

The petition asserts that there have been past allegations of improper welding practices and documentation, and installation of substandard piping at Seabrook Station and requests that the investigations of the RHR system pipe leakage include findings related to these past allegations and the implications of this incident for other plant systems. Each of these concerns is addressed below. 


\section{A. Root-Cause Analysis}

The Licensee has concluded that the cause of the RHR piping leak was chloride-induced transgranular stress-corrosion cracking initiated from the outside diameter of the pipe. The stress-corrosion cracking was the result of repeated wettings and dryings of a protective covering attached to the pipe with red duct tape during construction of the facility. The covering was installed to prevent other welding activities from damaging the pipe after it was installed and should have been removed prior to placing the RHR system in service. After being wetted the protective covering and tape leached chlorides, allowing the chlorides to concentrate on the outer surface of the pipe over time. The chlorides provided an agent to initiate stress-corrosion cracking of the stainless steel pipe material. The Licensee has conducted an inspection of accessible areas both inside and outside containment for similar instances of unapproved materials being attached to stainless steel piping and none were found.

The NRC Staff has reviewed the Licensee's conclusions, including observations of the failed pipe section and a review of the relevant metallurgical and chemistry reports. The NRC Staff found that the metallurgical and chemistry reports provide an adequate basis for the Licensee's conclusion that the leaks were the result of stress-corrosion cracking initiated from the outside diameter of the pipe that progressed through the pipe wall to the inside surface. The NRC Staff's findings are documented in Inspection Report 50-443/97-08.

\section{B. Review of Weld Documentation}

The Licensee conducted a review of the original radiographs of the affected welds and found no anomalies in the weld or the base metal. This finding indicates that the cause of the leakage was the result of service-induced conditions and not a weld or piping defect originating from the original construction.

The NRC Staff's review of the radiographs confirmed that there were no adverse construction weld quality problems, such as cracks, porosity, or weld slag shown on the pipe weld radiographs in the vicinity of the leaks or on the similar welds on the " $A$ " train of the RHR system. No defective welds were found. The NRC Staff's findings are documented in Inspection Report 50-443/97-08.

\section{Review of Pipe Qualification}

The Licensee reviewed the original material test reports and purchase specification documentation for the affected piping sections. Chemical analysis of the removed piping sections confirmed that the material met the specification for SA312 Type 304 stainless steel pipe. 
The NRC Staff's review of the chemistry analysis and photomicrographs showed the pipe material to be Type 304 stainless steel. The NRC Staff's findings are documented in Inspection Report 50-443/97-08.

\section{Review of the Procedures for Ongoing Assurance of Weld and Pipe Quality}

In conjunction with the most recent refueling outage at Seabrook Station, the NRC Staff conducted a review of the Licensee's American Society of Mechanical Engineers Boiler and Pressure Vessel Code (ASME Code) section XI inservice inspection program plan for ensuring structural and leaktight integrity of systems important to safety. The NRC inspector found the implementation of all elements of the program to be on schedule and in accordance with the rules of section XI of the ASME Code.

The NRC inspector observed and/or reviewed the results of inservice inspections conducted by the Licensee on plant equipment, including several piping welds. The NRC inspector found that the inspections were performed in accordance with the rules of section XI of the ASME Code and NRC regulations. The NRC Staff's findings are documented in Inspection Report 50-443/97-03.

\section{E. Review of Past Allegations of Improper Welding Practices}

On March 27, 1990, the NRC's Executive Director for Operations established an independent review team to conduct an assessment of the adequacy of the construction welding and nondestructive examination (NDE) practices at Seabrook Station. The team's findings are documented in NUREG-1425, "Welding and Nondestructive Examination Issues at Seabrook Nuclear Station." The independent review team concluded that the pipe welding and NDE programs were generally consistent with applicable codes and NRC requirements and resulted in technically acceptable pipe welds.

In investigating the leaks in the " $B$ " train of the RHR system reported on December 5, 1997, the NRC Staff did not identify any factors that would provide a basis for disagreeing with the Licensee's conclusion that the cause of the leakage was the result of service-induced conditions and not a weld or piping defect originating from the original construction. Likewise, the investigation of this issue did not provide any information that would question the validity of NUREG-1425. Therefore, no further action by the NRC Staff is warranted with respect to the past allegations of improper welding practices and substandard quality piping in response to the Petitioner's request. 


\section{F. Implications for Other Plant Systems}

The Licensee has concluded that the cause of the leakage in the " $\mathrm{B}$ " train of the RHR system reported on December 5, 1997, was the result of a serviceinduced condition and not a defect originating from the original construction. The NRC Staff has reviewed the Licensee's activities related to the root-cause analysis and subsequent repair in response to the RHR system pipe leakage. The NRC Staff found no evidence of improper welding practices or substandard piping that contributed to the RHR system pipe leakage and that would result in generic implications to other plant systems.

\section{CONCLUSION}

The NRC Staff has reviewed the information submitted by the Petitioner, and the Petitioner's request to suspend the operating license of the Seabrook Station is denied. As described above, the NRC Staff has found that the cause of the leaks in the piping in the " $B$ " train of the RHR system was the result of serviceinduced degradation. There were no deficiencies identified in the fabrication of the original piping or welds that would have generic implications for other plant systems and that would require the operating license of the facility to be suspended.

As provided in 10 C.F.R. $\$ 2.206$ (c), a copy of this Decision will be filed with the Secretary of the Commission for the Commission's review. This Decision will constitute the final action of the Commission 25 days after issuance, unless the Commission, on its own motion, institutes review of the Decision in that time.

\section{FOR THE NUCLEAR REGULATORY COMMISSION}

Samuel J. Collins, Director Office of Nuclear Reactor Regulation

Dated at Rockville, Maryland, this 17th day of March 1998. 